\title{
Inhalational Bacteriophage and Nanosilver Effectiveness on nCOVID-19: A Case Report
}

\author{
A. Hamad ${ }^{1}$, H. Alhiti2 ${ }^{2}$, M. Guma ${ }^{3}$, A. Mansour, M. Al-faham5, A. Al.Wasitty ${ }^{6}$ \\ ${ }^{1}$ Manager of Al Zahrawy Center for Stem Cells in Baghdad, Iraq \\ ${ }^{2}$ Head of Emergency Faculty in Higher Health Institute, General Surgeon Specialist M.D, Al Anbar Directorate of Health, Iraq \\ ${ }^{3}$ Department of Applied Chemistry, College of Applied Sciences- Hit, University Of Anbar, Iraq \\ ${ }^{4}$ Pharmacy Registrar, Al Azizia General Hospital, Doha, Qatar \\ ${ }^{5}$ Microbiology Department, College of Medicine, Baghdad University, Iraq \\ ${ }^{6} \mathrm{Head}$ of Department of Internal Medicine, Al-Karkh General Hospital, Iraq
}

*Corresponding author: Hazim Abdul Rahman Alhiti, Head of Emergency Faculty in Higher health institute, General Surgeon Specialist M.D, Al Anbar Directorate of Health, Iraq

Received date: May 16, 2021; Accepted date: June 1, 2021; Published date: June 8, 2021

Citation: Hamad A, Alhiti H, Guma M, et al. (2021) Inhalational Bacteriophage and Nanosilver Effectiveness on nCOVID-19: A Case Report. J Med Res Surg 2(3): pp. 1-5. doi: 10.52916/jmrs214046

Copyright: (C2021 Hamad A, et al. This is an open-access article distributed under the terms of the Creative Commons Attribution License, which permits unrestricted use, distribution and reproduction in any medium, provided the original author and source are credited.

\section{ABSTRACT}

This is a case report of an immunocompromised plus (nCOVID-19) infected elderly Iraqi man in the AL-KARAMA respiratory care unit. Consequently, this man presented on $2 / 6 / 2020$ following accelerated respiratory deterioration over two days with positive PCR and CT scan confirmation. Ordinarily, SPO $84 \%$ at room temp despite the oxygen administration $4 \mathrm{~L} / \mathrm{min}$, not intubated. Therefore, the physician staged this case as $\mathrm{llb}$ according to clinical staging for nCOVID-19. Moreover, he had uncontrolled IDDM and right nephrectomy for renal cell carcinoma before three years. Although, the physician applied nCOVID-19 guidelines of the ministry of Health-Iraq for three days but without a response. So, the researchers added an Inhalational Bacteriophage solution to an Inhalational Nanosilver colloid (designated by the authors) alternative after patient consent. Interestingly, there were fast and notable improvements in the patient's overall health plus relief of the respiratory symptoms. Consequently, a continuous increase in his SPO2 over the next day approaching $97 \%$. Moreover, an improvement in his speaking and walking commencing to discharge well plus a negative PCR. Thus, the Inhalational Bacteriophage and Nanosilver are the most beneficial treatment including the prevention of nCOVID-19 complications in all stages.

\section{Keywords:}

nCOVID-19, CORONA, Inhalational, Bacteriophage, Nano-silver.

\section{Abbreviations:}

IDDM: Insulin Dependent Diabetes Mellitus; ml: Milliliter; PCR: Polymerase Chain Reaction; CT: Computed Tomography.

\section{Introduction}

nCOVID-19 is a viral infection that started in Wuhan and produced a universal pandemic outbreak all over the world countries [1]. Generally, Bacteriophages (phages) denotes viruses that replicate and infect the pathogenic bacteria. Therefore, phages consist of special proteins that capture an RNA or DNA genome [2]. Moreover, Nanosilver has a unique killing effect on viruses, bacteria, and fungi [3]. Nanosilver restrains a pathogenic organism's expression of the protein capable of reproduction [4]. So, Nano-silver represses the viruses that responsible for respiratory infections particularly at the beginning of the respiratory symptoms [5]. Therefore, many researchers from the world nations investigated nCOVID-19 for epidemiological, clinical, and therapeutic behaviors [6].

\section{Case Report}

An elderly (68years) immunocompromised Iraqi male presented on 2-6-2020 to AL KARKH respiratory care unit following rapid respiratory deterioration over two sequential days. Accordingly, PCR test was positive plus $C T$ scan verified lung infiltration
$50 \%, \mathrm{SPO}_{2} 84 \%$ on room temp despite oxygen administration on a rate of $4 \mathrm{~L} / \mathrm{min}$, but not intubated. Moreover, the initial diagnosis is an nCOVID-19 infection as a Stage IIb, according to the clinical and therapeutic staging scheme for COVID-19 [7]. Although, he had controlled IDDM during the last three years plus a right nephrectomy for renal cell carcinoma three years ago. Accordingly, the physician applied nCOVID-19 guidelines of

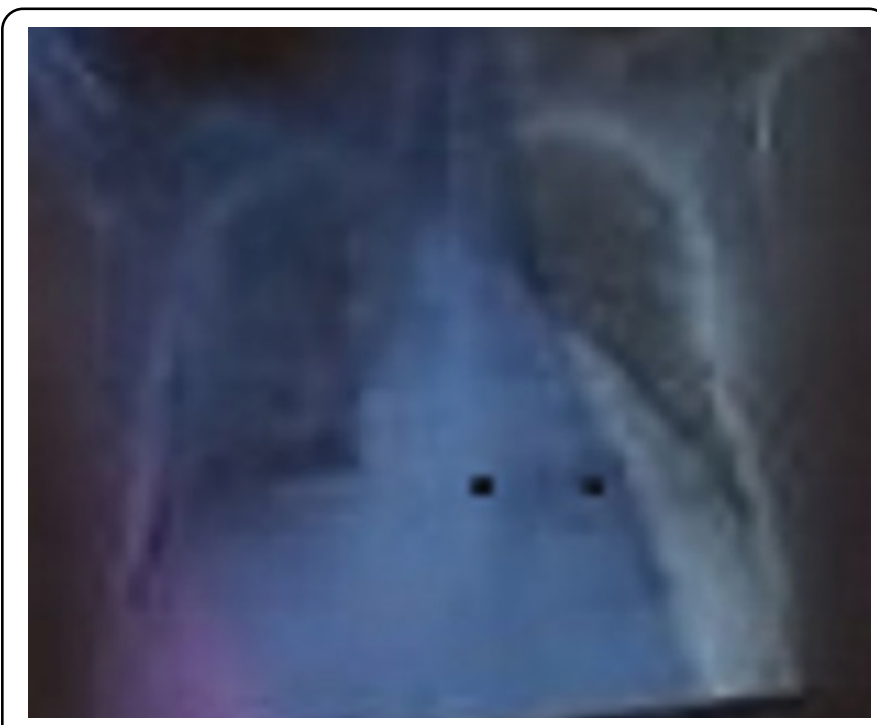

Figure 1: Showing chest X-Ray of our patient with bilateral lung infiltrations. 
the ministry of Health-Iraq during the last two days but without a response. Ordinarily, the polymerase chain reaction test is positive at admission by using Smart-32 Nucleic Acid Extraction Instrument http://en.daangene.com/. The chest X-Ray of the patient demonstrates a loss of the normal black appearance in the lung plus consolidation opacities (Figure1).

Furthermore, the CT scan at admission. Figure (2-6)

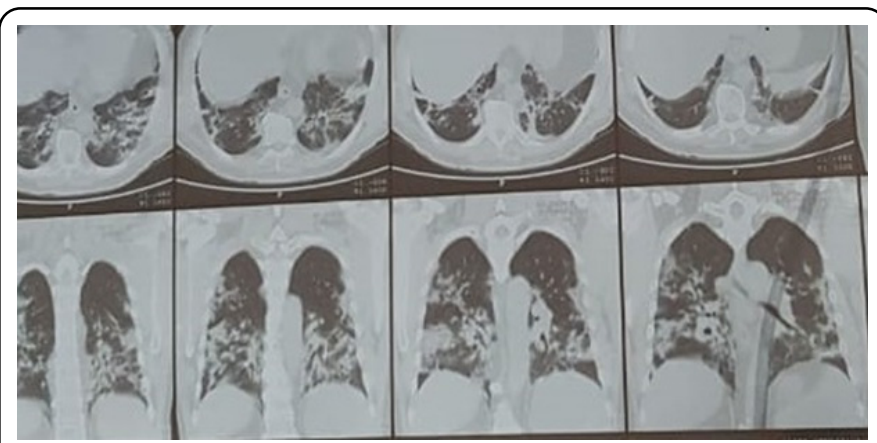

Figure 2: Showing CT scan of our patient with bilateral lung infiltrations.

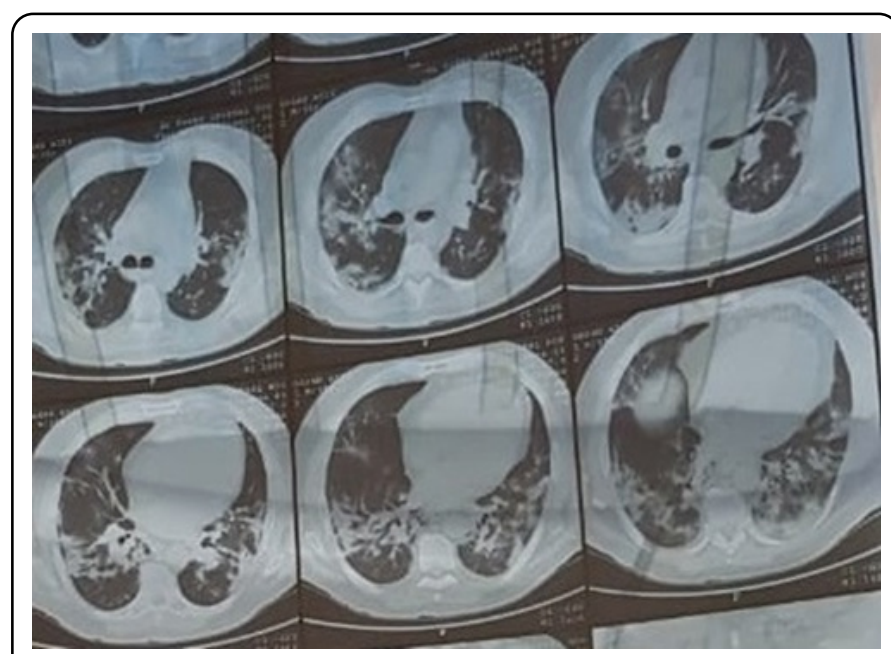

Figure 3: Showing CT scan of our patient with bilateral lung infiltrations.

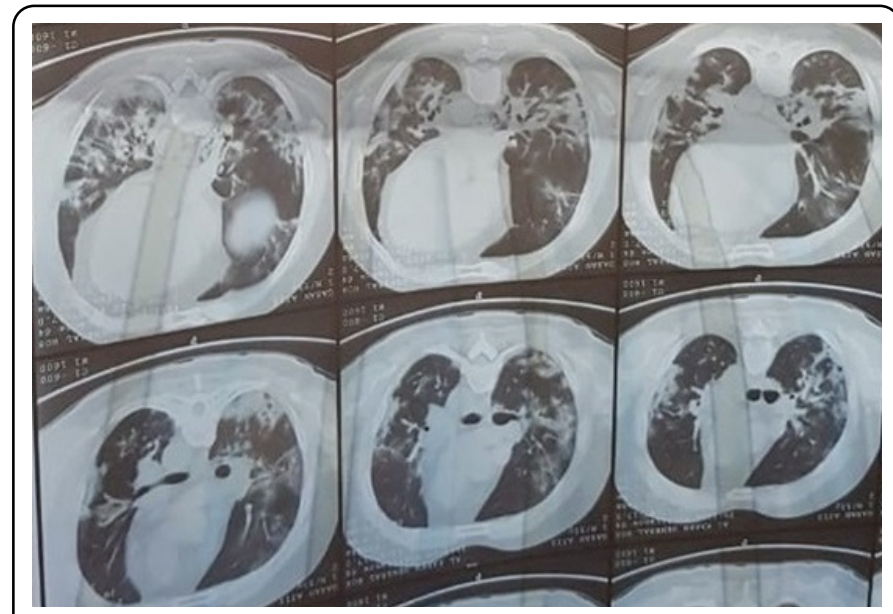

Figure 4: Showing CT scan of our patient with bilateral lung infiltrations.

CT scan at admission: radiological report

1. consolidation of right middle and lower zone ground-glass opacification

2. peripheral distribution of both lobes

3. lung infiltrations more than $50 \%$

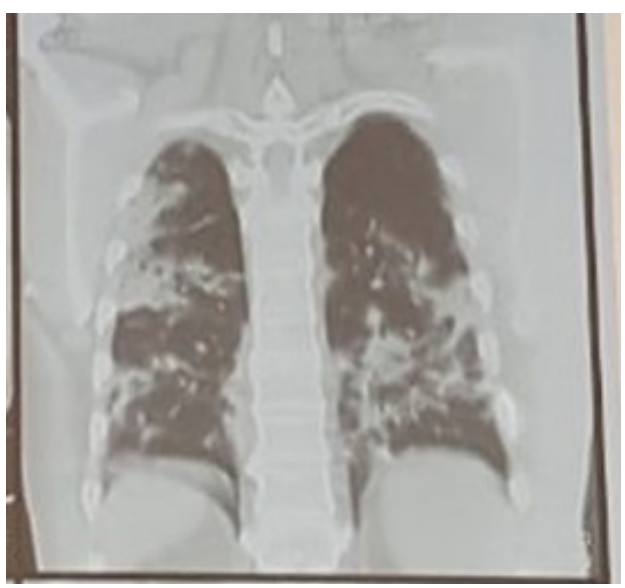

Figure 5: Showing CT scan of our patient with bilateral lung infiltrations.

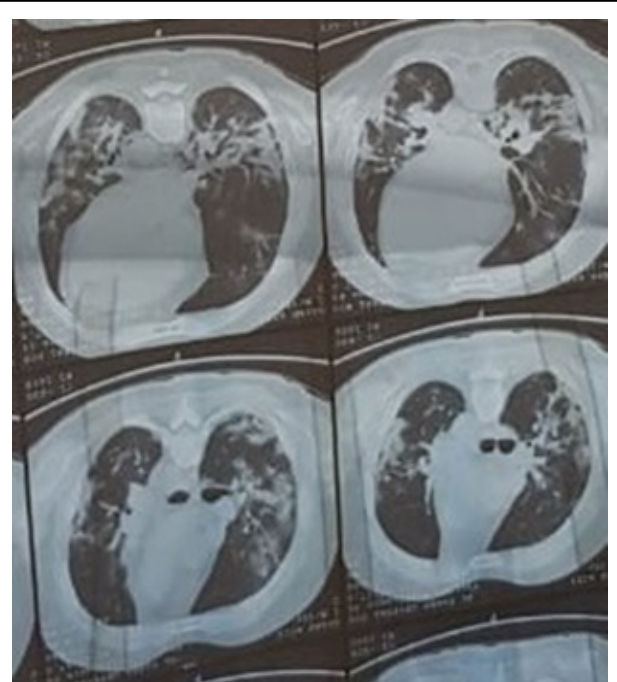

Figure 6: Showing CT scan of our patient with bilateral lung infiltrations.

nCOVID-19 guidelines of the ministry of Health-Iraq includes;

1. Hydroxychloroquine tab oral $200 \mathrm{mg} 1 \times 2$

2. Azithromycin capsule oral $250 \mathrm{mg} 1 \times 1$

3. Paracetamol tab oral $500 \mathrm{mg} 1 \times 3$

4. Zantac ampule I.V $50 \mathrm{mg} 1 \times 2$

5. Oxygen $4 \mathrm{~m} / \mathrm{L}$ on need

6. Tamiflu tab oral $75 \mathrm{mg} 1 \times 2$

7. Clexane vial 6000 I.U subcutaneous

8. Antiretroviral Medication - KALETRA ${ }^{\circledR}$ (lopinavir/ritonavir) Tab oral $2 \times 2$

9. Insulin Soluble subcutaneous $1 \times 3$ according to the reading 10. Ceftriaxone vial $1000 \mathrm{mg} / \mathrm{dl} \mathrm{I} . \mathrm{V} 1 \times 2$

Despite all these drugs, this man suffered more increasing dyspnea and a progressive decrease in $\mathrm{SPO}_{2}$ plus a high fever (Temperature 39.2), difficulty in speaking, eating, and walking. But, because of busy ventilators, the physicians not intubated this patient. Furthermore, he had an uncontrolled blood sugar of $17 \mathrm{mmol} / \mathrm{L}$ plus deteriorating renal function tests (S. Creatinine $216 \mathrm{Umol} / \mathrm{L}$ and Blood Urea $8 \mathrm{Umol} / \mathrm{L})$, S. sodium $138 \mathrm{mmol} / \mathrm{L}$, s. Potassium $4 \mathrm{mmol} / \mathrm{L}, \mathrm{S}$. calcium $1.4 \mathrm{mmol} / \mathrm{L}, \mathrm{S}$. chloride 98 $\mathrm{mmol} / \mathrm{L}$. Differential White blood cells count is in Figure 7-9 beside the ESR $86 \mathrm{~mm} / \mathrm{hr}$ moreover the ECG returned normal. 


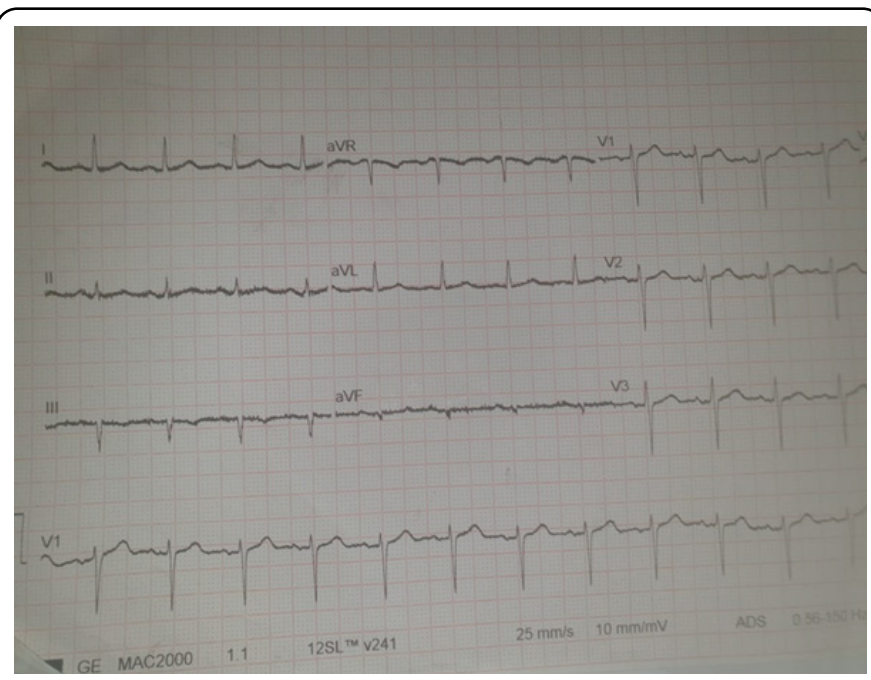

Figure7: Showing ECG of our patient at admission.

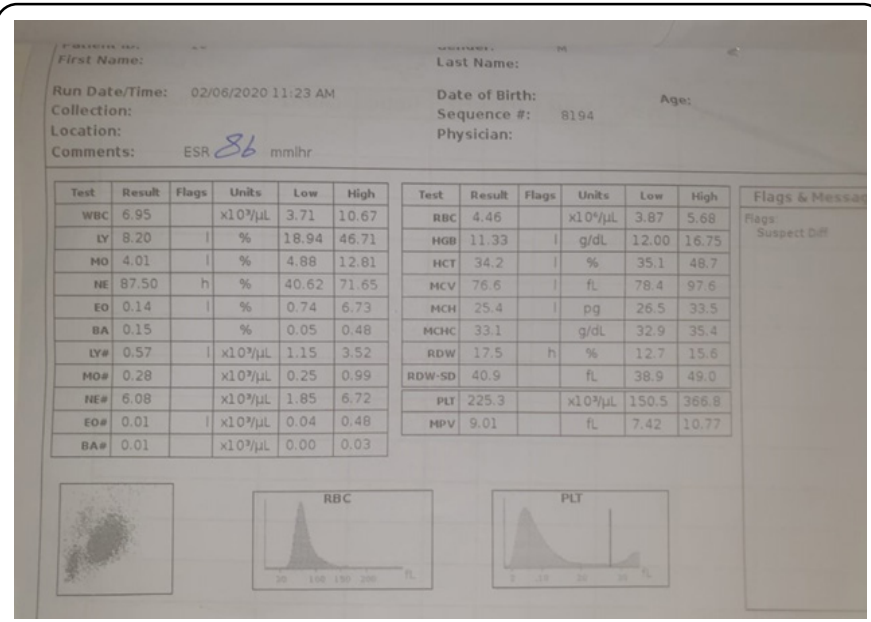

Figure 8: Showing differential White blood cells at admission 2/6/2020.

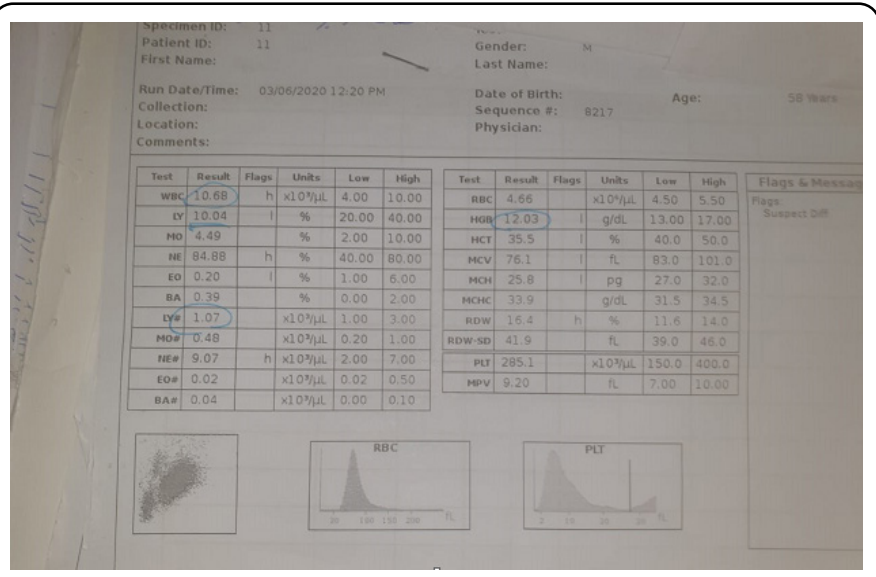

Figure 9: Showing differential White blood cells at admission 3/6/2020.

The researchers discussed with the patient and his family the new modality of treatment and oral consented to this regimen. Then the researchers supplemented Inhalational delivery Bacteriophage solution every six hours for 48 hours then Nanosilver colloid every eight hours in an intermittent course.

\section{Discussion}

This is the first case report in the world that described the value of Inhalational Bacteriophage and Nanosilver in a verified case of immunocompromised nCOVID-19 patient. Amazingly, the obvious evidence of improvement is clear by the continuous rise of his $\mathrm{SPO}_{2}$ to $97 \%$ over the next 24 hours. Moreover, the vital signs improved by the drop in his pulse rate ( 85 beats/min) and stabilization of blood pressure (135/87 $\mathrm{mmHg})$, and regular respiratory rate $(22 / \mathrm{min})$. Consequently, his temperature decreased in the next four hours on the monitoring chart (temperature 39.2 to $37.8 \mathrm{C}$ ). Further, his speaking and walking become better, and then discharged well. So, there were successful and accelerated improvements in his general condition and particularly the respiratory symptoms which mean the healing of this patient. This result is equivalent to the established reports [8].

Furthermore, the polymerase chain reaction test is negative at discharge that indicates nCOVID -19 disappearances. Moreover, there was a drop in the blood sugar levels via venous aspiration from $9 \mathrm{mmol} / \mathrm{L}$ to $6 \mathrm{mmol} / \mathrm{L}$, renal function test was high at his admission, (S. Creatinine $216 \mathrm{Umol} / \mathrm{L}$ and Blood Urea $8 \mathrm{Umol} / \mathrm{L}$ ) return to normal, and electrolytes were normal at discharge. Differential White blood cell count returned to normal at discharge. The importance of Differential White blood cell count is to monitor patient cellular response in acute chest and abdominal diseases [9].

After that, the total White blood cell count returned to $7.4 \times$ 109 plus the packed cell volume increased to 33\%. Moreover, the liver enzymes and liver functions dropped to normal. Furthermore, the ECG records maintained normal sinus rhythm, non-specific $T$ wave abnormality without abnormalities; QRS: $90 \mathrm{~ms}, \mathrm{P} / \mathrm{QRS} / \mathrm{T}$ : 40/-8/9 degrees. So, this man owned real improvement after adding Inhalational bacteriophage to the Nanosilver which is more effective and rapid response than the previous approach (Inhalational Nanosilver only) [10]. The Iraqi peoples rely on oral consent and not familiar with written consent, they consider it as a suspicious paper due to ethnic conflict.

\section{Conclusions}

Inhalational Bacteriophage and Nanosilver are the best adjuvant therapy and prevent complications from all stages of nCOVID-19. Moreover, Inhalational Bacteriophage and Nanosilver had antiviral therapeutic benefits against nCOVID-19.

\section{Funding: No funding}

\section{Acknowledgment:}

Abbas Khudair Abbas Al.Wasitty, Head of Internal Medicine department, Al-Karkh General Hospital.

\section{References}

1. Huang C, Wang Y, Li X, et al. (2020). Clinical features of patients infected with 2019 novel coronavirus in Wuhan, China. Lancet 395(10223): pp. 497-506.

2. Nikolich MP, Filippov AA. (2020) Bacteriophage Therapy: Developments and Directions. Antibiotics 9(3): pp. 135.

3. Peng G, Huma ZE, Umair M, et al. (2020) Chapter 8 - Nanosilver at the interface of biomedical applications, toxicology, and. 
synthetic strategies. Metal Nanoparticles for Drug Delivery and Diagnostic Applications Micro and Nano Technologies pp. 119139.

4. Zachar O. (2020) Formulations for COVID-19 Early Stage Treatment via Silver Nanoparticles Inhalation Delivery at Home and Hospital. ScienceOpen.

https://www.scienceopen.com/hosteddocument ?doi=10.14293/S2199-1006.1.SOR-.PPHBJEO.v1

5. Dorothea M. (2019). Antiviral and Immunomodulatory Activity of Silver Nanoparticles in Experimental RSV Infection. Viruses 11(8): pp. 732- 738.

6. Siddiqi HK, Mandeep R, Mehra MR (2020) A clinicaltherapeutic staging proposal COVID-19 illness in native and immunosuppressed states: a clinical-therapeutic staging proposal. Journal of Heart and Lung Transplant 39(5): pp. 405407.
7. Xu B, Xing Y, Peng J. et al. (2020) Chest CT for detecting COVID-19: a systematic review and meta-analysis of diagnostic accuracy. Eur Radiol 2020: pp. 231-240.

8. Garibaldi BT, Wang K, Robinson ML, et al. (2021) Comparison of Time to Clinical Improvement With vs Without Remdesivir Treatment in Hospitalized Patients With COVID-19. JAMA Netw Open 4(3): pp. e213071.

9. Alhiti HAR, Guma MA, Dikheel TR (2020) The Impact of the Differential White Blood Cells in the Diagnosis of the Acute Right Iliac Fossa Pathology. BRIAC 10(5): pp. 6082-6087.

10. Dheyab MA, Khani PM, AbdulAziz A, et al. (2021) Focused role of nanoparticles against COVID-19: Diagnosis and treatment. Photodiag and Photodyn Ther 34: pp. 102287. 